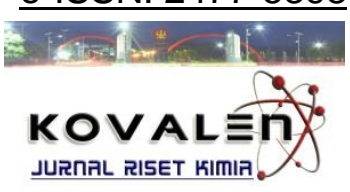

\title{
PEMBUATAN KONSENTRAT PROTEIN DARI BIJI KELOR (Moringa oleifera L.) DAN ANALISIS PROFIL ASAM AMINO
}

\section{[The Production of Protein Concentrate from Moringa Seed (Moringa oleifera L.) and its Amino Acid Profile Analysis]}

\author{
Nurhayati $^{1^{\star}}$, Mappiratu $^{1}$, Musafira $^{2}$ \\ 1) Jurusan Kimia Fakultas MIPA, Universitas Tadulako \\ Jl. Soekarno Hatta Km.9, Kampus Bumi Tadulako Tondo Palu, Telp. 0451- 422611 \\ 2) Universitas Sulawesi Barat, Majene \\ *)Coresponding author: noerchemz@yahoo.co.id
}

Diterima 6 Desember 2017, Disetujui 25 Januari 2018

\begin{abstract}
A reasearch about the production of protein concentrate from moringa seeds and analysis of amino acid profiles have been conducted. The aim of the reasearch is to determine the degree of saturation of ammonium sulphate with high rendament and protein content, ti determine the ratio of ammonium sulphate toward moringa seeds with high rendament and also high protein content, and to determine the amino acid profile of moringa seed protein concentrate. The completely randomized design (CRD) was used in the reasearch, with 6 variations of ammonium sulphate saturation degree and 5 variations of the ratio of moringa seed flour toward ammonium sulphate $(50 \%, 60 \%, 65 \%, 70 \%, 75 \%$, $80 \%$ and $1: 2,1: 3,1: 4,1: 5$, and $1: 6(\mathrm{w} / \mathrm{v})$ respectively). Each treatment was done in triplo. The best degree of saturation of ammonium sulphate was $65 \%$ with $46.56 \%$ of the rendament and $72.19 \%$ of protein content. The best ratio of moringa seed flour toward ammonium sulphate was 1:6. It has $70.96 \%$ of rendament and $74.16 \%$ of protein content. The amino acid profile consist of essential amino acid and non essential amino acids. The components of those amino acids were arginine $(77.3$ $\mathrm{mg} / \mathrm{g})$, phenylalanine $(27.61 \mathrm{mg} / \mathrm{g})$, leucine $(27.39 \mathrm{mg} / \mathrm{g})$, valine $(15.19 \mathrm{mg} / \mathrm{g})$, isoleucine $(13.16$ $\mathrm{mg} / \mathrm{g})$, histidine $(13,16 \mathrm{mg} / \mathrm{g})$, threonine $(11,29 \mathrm{mg} / \mathrm{g})$, methionine $(10.67 \mathrm{mg} / \mathrm{g})$ lysine $(7.57 \mathrm{mg} / \mathrm{g})$, triptofan $(3.49 \mathrm{mg} / \mathrm{g})$ and glutamc acid $(97.2 \mathrm{mg} / \mathrm{g})$, proline $(26.3 \mathrm{mg} / \mathrm{g})$, glysine $(24.74 \mathrm{mg} / \mathrm{g})$, alanine $(17.57 \mathrm{mg} / \mathrm{g})$, aspartic acid $(17.45 \mathrm{mg} / \mathrm{g})$, serine $(15.16 \mathrm{mg} / \mathrm{g})$, tyrosine $(11.29 \mathrm{mg} / \mathrm{g})$, cystein $(5,9$ $\mathrm{mg} / \mathrm{g}$ ) respectively.
\end{abstract}

Keywords : Amino acids profile, moringa seeds, protein concetrate.

\section{ABSTRAK}

Penelitian tentang pembuatan konsentrat protein dari biji kelor dan analisis profil asam amino telah dilakukan, dengan tujuan untuk menentukan tingkat kejenuhan amonium sulfat yang menghasilkan konsentrat protein dengan rendemen dan kadar protein tertinggi, rasio tepung biji kelor terhadap amonium sulfat yang menghasilkan konsentrat protein dengan rendemen dan kadar protein tertinggi, dan mengetahui profil asam amino konsentrat protein biji kelor. Penelitian ini dilakukan dengan menggunakan rancangan acak lengkap (RAL), dengan variasi tingkat kejenuhan amonium sulfat $50 \%, 60 \%, 65 \%, 70 \%, 75 \%, 80 \%$ dan variasi rasio tepung biji kelor terhadap amonium sulfat $1: 2,1: 3$, 1:4, 1:5, dan 1:6 (b/v), setiap perlakuan dilakukan sebanyak 2 kali. Tingkat kejenuhan amonium sulfat terbaik diperoleh pada $65 \%$ dengan rendemen sebesar $46,56 \%$ dan kadar protein $72,18 \%$. Rasio amonium sulfat terhadap tepung biji kelor diperoleh rasio terbaik 1:6 dengan rendemen sebesar $70,96 \%$ dan kadar protein sebesar $74,16 \%$. Profil asam amino konsnentrat protein biji kelor yaitu asam amino essensial berupa arginin $(77,3 \mathrm{mg} / \mathrm{g})$, fenilalanin $(27,61 \mathrm{mg} / \mathrm{g})$, leusin $(27,39 \mathrm{mg} / \mathrm{g})$, valin $(15,19 \mathrm{mg} / \mathrm{g})$, isoleusin $(13,16 \mathrm{mg} / \mathrm{g})$, threonin $(11,29 \mathrm{mg} / \mathrm{g})$, metionin $(10,67 \mathrm{mg} / \mathrm{g})$, lisin $(7,57 \mathrm{mg} / \mathrm{g})$, dan triptofan (3,49 mg/g). Asam amino non essensial berupa asam glutamat $(97,2 \mathrm{mg} / \mathrm{g})$, prolin $(26,3$ $\mathrm{mg} / \mathrm{g})$, glisin $(24,74 \mathrm{mg} / \mathrm{g})$, alanin $(17,57 \mathrm{mg} / \mathrm{g})$, asam aspartat $(17,45 \mathrm{mg} / \mathrm{g})$, serina $(15,16 \mathrm{mg} / \mathrm{g})$, tirosin $(11,29 \mathrm{mg} / \mathrm{g})$, dan sistina $(5,9 \mathrm{mg} / \mathrm{g})$.

Kata kunci : Asam amino essensial biji kelor, Biji kelor, Konsentrat protein, Profil asam amino 


\section{LATAR BELAKANG}

Lembah Palu merupakan salah satu daerah yang memiliki iklim yang sangat sesuai untuk tanaman kelor (Moringa oleifera L.) tumbuh dengan subur (Laguni, 2012). Tanaman ini banyak dimanfaatkan oleh masyarakat Palu sebagai sayuran, baik daun maupun buahnya. Akan tetapi, banyak pula buah kelor yang jika telah kering hanya terbuang percuma, tidak terkecuali bagian bijinya. Biji buah kelor berbentuk bulat dan bila sudah tua akan bertekstur agak keras. Dilain pihak biji buah kelor dapat dimanfaatkan untuk berbagai terapan, selah satunya sebagai sumber protein, sebagaimana menurut AlKhalili, et al. (1997) dalam Srawaili (2008), biji tersebut mengandung protein $38,4 \%$.

Protein termasuk jenis makromolekul yang sangat dibutuhkan oleh tubuh manusia sebagai zat gizi (Muchtadi, 2009). Jenis dan jumlah asam amino penyusun protein sangat menentukan kualitas dari protein tersebut (Toha, 2001 dalam Hermiastuti, 2013). Yuniastuti (2008) mengemukakan bahwa protein memiliki mutu tinggi apabila mengandung semua jenis asam amino essensial yang dapat memberikan manfaat optimal bagi pertumbuhan.

Kekurangan makanan yang mengandung protein merupakan sa;ah satu masalah yang selalu dihadapi oleh negara-negara berkembang termasuk Indonesia (Purwitasari et al., 2014). Hal tersebut dapat diatasi melalui pembuatan dan pemanfaatan konsentrat protein.
Konsentrat protein didefinisikan sebagai protein dalam bentuk pekat dengan kadar protein paling sedikit $50 \%$. Protein jenis ini dibuat dengan cara menghilangkan senyawa karbohidrat, lemak, mineral, dan air yang termasuk nonprotein, sehingga kadar protein akan lebih tinggi dibandingkan bahan bakunya (Amoo, et al., 2006 dalam Karnila, et al., 2011). Pemanfaatan konsentrat protein diarahkan sebagai bahan baku dalam industri pangan, seperti industri roti dan makanan tambahan (Purwitasari et al., 2014).

Konsentrat protein dari hewan maupun tumbuhan dapat dibuat dengan beberapa cara, salah satunya dengan menggunakan garam amonium sulfat secara pengendapan (salting out). Metode ini merupakan metode banyak digunakan dalam pengendapan protein ataupun enzim dari suatu bahan. Senyawa amonium sulfat merupakan jenis garam dengan kekuatan ionik yang tinggi (Matthews et al., 2000 dalam Su'i, 2013), kelarutan tinggi dalam air, murah (Wang, 2004 dalam Su'i, 2013), tidak berbahaya, dan memiliki efek penstabil enzim serta tidak merusak protein sehingga banyak dimanfaatkan pada metode ini (Chaplin et al., 2004 dalam Su'i, 2013).

Penelitian yang dilakukan oleh Purwitasari et al. (2014), mengenai pengaruh suhu dan waktu ekstraksi terhadap sifat kimia dalam pembuatan konsentrat protein kacang komak menggunakan pelarut etanol $95 \%$ dengan rasio 1:2 (b/v) diperoleh hasil terbaik 
dengan kadar protein tertinggi pada suhu ekstraksi $30^{\circ} \mathrm{C}$ selama 60 menit dengan rendemen $93,10 \%$.

Isolasi enzim protease menggunakan amonium sulfat telah banyak dilakukan, salah satunya protease dari getah tanaman biduri menggunakan ammonium sulfat $65 \%$ (Hardi dan Diharnaini, 2014; Witono et al., 2006). Selain itu, Bahri et al. (2012) mengisolasi enzim amilase dari kecambah biji jagung ketan melalui salting out enzim dengan tingkat kejenuhan ammonium sulfat $55 \%$. Berdasarkan beberapa kajian di atas, maka perlu dilakukan penelitian mengenai tingkat kejenuhan amonium sulfat dan rasionya terhadap tepung biji kelor yang optimal untuk konsentrat protein terbaik serta profil asam amino untuk mengetahui kualitas proteinnya biji kelor.

\section{METODE PENELITIAN}

\section{Bahan dan Peralatan}

Bahan yang digunakan : biji kelor, $n$ heksan, amonium sulfat $\left(\left(\mathrm{NH}_{4}\right)_{2} \mathrm{SO}_{4}\right)$ tehnis, aquades, kertas saring, $\mathrm{NaOH} 1 \mathrm{~N}$, $\mathrm{HCl} 6 \mathrm{~N}$, alpha aminobutyric acid (AABA), aquabidest, AccQ-flour borate, reagen flour $\mathrm{A}$.

Alat yang digunakan : blender, ayakan 60 mesh, neraca analitik, seperangkat alat soxhlet, penyaring Buchner, mesin kocok, spektrofotometer UV-Visible (perkinElmer Lambda 25), Kromatografi Cair Kinerja Tinggi (KCKT), dan alat-alat gelas yang umum digunakan dalam laboratorium kimia.

\section{Prosedur Penelitian}

\section{Pembuatan Tepung Biji Kelor}

Buah kelor yang sudah tua diambil bijinya, kemudian dikeringkan. Biji kelor yang sudah kering dihilangkan kulit arinya, kemudian dikeringkan dibawah sinar matahari. Biji kelor yang kering diblender dan diayak menggunakan ayakan 60 mesh hingga diperoleh tepung biji kelor

\section{Ekstraksi Lemak Tepung Biji Kelor (Sanusi dan Sitorus, 2013)}

Ekstraksi lemak tepung biji kelor dilakukan dengan metode soxhletasi tepung biji kelor dimasukkan ke dalam solongsong kertas, disumbat dengan kapas, kemudian dimasukkan ke dalam alat soxhlet yang dihubungkan dengan labu lemak yang telah dikeringkan. Residu kemudian dikeluarkan dari solongsong dan diangin-anginkan hingga kering. Tepung biji kelor hasil ekstraksi dihaluskan kemudian disimpan ddalam wadah tertutup.

\section{Pembuatan Konsentrat Protein Biji Kelor}

\section{Penentuan Tingkat Kejenuhan Amonium Sulfat (Modifikasi Cara Timumun, 2012)}

Sebanyak 6 buah gelas kimia dimasukkan tepung biji kelor hasil ekstraksi masing-masing sebanyak $25 \mathrm{~g}$, kemudian ke dalam masing-masing gelas kimia ditambahkan amonium sulfat tingkat kejenuhan 50\%, 60\%, 65\%, 70\%, 75\%, dan $80 \%$ sebanyak $100 \mathrm{~mL}$. Selanjutnya diaduk selama 10 menit dan disimpan dalam lemari pendingin selama 24 jam. 
Konsentrat protein yang terletak di permukaan campuran, kemudian dipisahkan dari fasa cairnya dengan cara vakum sambil dibilas dengan aquades. Konsentrat protein dalam keadaan basah tersebut kemudian dikeringkan dalam oven dengan suhu $60{ }^{\circ} \mathrm{C}$ selama 12 jam. Konsentrat protein kering ditimbang, dihitung rendemennya kemudian dihaluskan. Setelah itu, dimasukkan dalam wadah dan disimpan dalam lemari pendingin.

Rendemen $=\frac{\text { Massa konsentrat protein tepung biji kelor }}{\text { Massa tepung biji kelor }} \times 100 \%$

\section{Penentuan Rasio Tepung Biji Kelor terhadap Amonium Sulfat (Modifikasi Cara Timumun, 2012)}

Tepung biji kelor ditimbang sebanyak

$25 \mathrm{~g}$, kemudian di masukkan ke dalam gelas kimia. Selanjutnya, ditambahkan dengan amonium sulfat tingkat kejenuhan terbaik yang diperoleh pada perlakuan sebelumnya dengan rasio $1: 2,1: 3,1: 4$, 1:5, dan 1:6 (b/v), kemudian diaduk selama 10 menit dan disimpan dalam lemari pendingin selama 24 jam. Konsentrat protein dipisahkan dari fasa cainnya dengan cara vakum sambil dibiiloas dengan aquades. Konsentrat protein dikeringkan dalam oven dengan suhu $60{ }^{\circ} \mathrm{C}$ selama 12 jam, setelah itu ditimbang, dihitung rendemennya kemudian dihaluskan. Konsentrat protein tersebut dimasukkan dalam wadah dan disimpan dalam lemari pendingin.
Analisis Kadar Protein dengan Metode Spektrofotometri (Sumantri, 2007)

Konsentrat protein yang diperoleh ditimbang sebanyak $0,25 \mathrm{~g}$ dimasukkan dalam Erlenmeyer $250 \mathrm{~mL}$ kemudian ditambahkan $50 \mathrm{~mL} \mathrm{NaOH} 1 \mathrm{~N}$. Campuran dikocok di atas mesin kocok selama 1 jam. Larutan yang telah dikocok, kemudian disaring. Filtrat yang diperoleh diambil $5 \mathrm{~mL}$ kemudian dimasukkan ke dalam labu ukur $25 \mathrm{~mL}$ dan ditambahkan $\mathrm{NaOh} 1 \mathrm{~N}$ sampai garis batas. Filtrat hasil pengenceran diukur serapannya pada panjang gelombang $(\lambda) 280 \mathrm{~nm}$ dan 260 $\mathrm{nm}$ menggunakan spektrofotometer UVVIS. Serapan yang terbaca, digunakan untuk menghitung kadar protein dengan menggunakan persamaan :

Kadar protein $(\%)=\frac{\mathrm{A}_{280} \times \mathrm{FK} \times \mathrm{FP} \times \mathrm{V}_{\mathrm{NaOH}}}{1000 \times \text { berat sampel }} \times 100 \%$ Keterangan :

FK (Faktor Koreksi) $=$ A280/A260

$\mathrm{FP}=$ Faktor Pengenceran

\section{Analsisi Profil Asam Amino dengan Metode KCKT (Elfita, 2014)}

Konsentrat protein ditimbang sebanyak $0,1 \mathrm{~g}$, kemudian ditambahkan 5 $\mathrm{mL} \mathrm{HCl} 6 \mathrm{~N}$ dan divortex, dihidrolisis selama 22 jam pada suhu $110^{\circ} \mathrm{C}$, setelah itu didinginkan. Larutan dipindahkan ke labu ukur $50 \mathrm{~mL}$, kemudian ditambahkan aquabides sampai tanda batas. Larutan kemudian disaring dengan filter 0,45 $\mu \mathrm{m}$. Filtrat yang dihasilkan, diambil sebanyak $500 \mu \mathrm{L}$, ditambahkan $40 \mu \mathrm{m}$ AABA \pm 460 $\mu \mathrm{L}$ aquabides. Campuran tersebut dipipet sebanyak $10 \mu \mathrm{L}$, ditambahkan $70 \mu \mathrm{L}$ 
AccQ-Flour Borate kemudian divortex, setelah itu ditambahkan $20 \mu \mathrm{L}$ reagen flour $A$, divortex dan didiamkan selama 1 menit. Larutan itu diinkubasi selama 10 menit pada suhu $55{ }^{\circ} \mathrm{C}$, kemudian disuntikan pada injektor KCKT.

\section{HASIL DAN PEMBAHASAN}

\section{Konsentrat Protein pada Berbagai Tingkat Kejenuhan Amonium Sulfat}

Pemisahan protein dilakukan dengan metode salting out. Hasil yang diperoleh (Gambar 1) menunjukkan rendemen semakin meningkat seiring bertambahnya tingkat kejenuhan amonium sulfat sampai pada tingkat kejenuhan $65 \%$. Namun rendemen menurun pada tingkat kejenuhan setelahnya. Menurut Nooralabettu (2014), peningkatan tingkat kejenuhan amonium sulfat dapat meningkatkan koagulasi protein karena beberapa bagian hidrofilik terkoagulasi pada tingakt kejenuhan amonium sulfat yang lebih rendah dan beberapa protein dengan bagian hidrofilik terkoagulasi pada tingkat kejenuhan yang lebih tinggi.

Tingkat kejenuhan untuk koagulasi protein itu berbeda-beda, bergantung pada jenis bahan dasar yang digunakan. Tingkat kejenuhan untuk mengkoagulasi enzim amilase dari kecambah biji jagung ketan tingkat kejenuhan terbaik yaitu pada 65\% (Bahri, et al., 2012), sementara tingkat kejenuhan amonium sulfat terbaik untuk enzim lipase dari dua bahan berbeda yaitu dedak padi pada $65 \%$ (Hutomo, 2004) dan koagulasi protein dari getah biduri pada tingkat kejenuhan 55\% (Rahmawati, 2009).

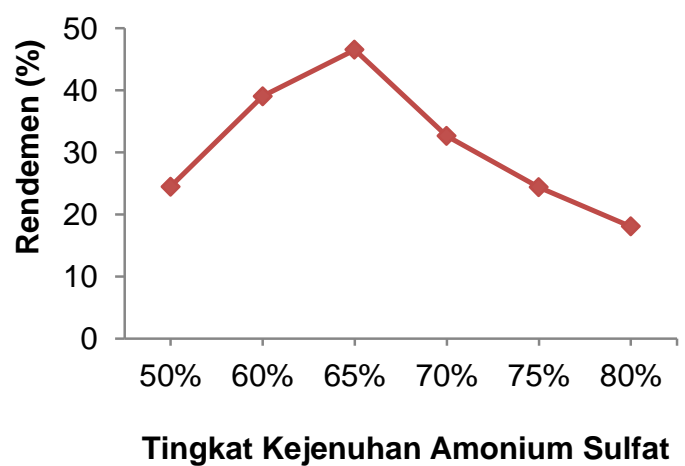

Gambar 1 Grafik hubungan pengaruh tingkat kejenuhan terhadap rendemen konsentrat protein

Hasil uji sidik ragam menunjukkan bahwa tingkat kejenuhan amonium sulfat berpengaruh nyata pada rendemen konsentrat protein tepung biji kelor yang dihasilkan. Hasil analisis lanjut menggunakan BNJ menunjukkan masingmasing tingkat kejenuhan 50\%, 60\%, $70 \%$, dan $75 \%$ mempunyai rendemen yang berbeda tidak nyata, sementara pada tingkat kejenuhan $65 \%$ dan $80 \%$ rendemennya berbeda sangat nyata.

Kadar Protein Konsentrat Protein Biji Kelor dari Berbagai Tingkat Kejenuhan Amonium Sulfat

Kadar protein pada suatu konsentrat protein sangat berpengaruh pada kualitas konsentrat tersebut. Konsentrat protein harus memiliki minimal kadar protein $50 \%$. Jumlah kadar protein dalam suatu bahan pangan, menentukan kepadatan protein pangan tersebut (Tejasari, 2005).

Berdasarkan hasil yang diperoleh (Gambar 2) menunjukkan kadar protein meningkat seiring bertambahnya tingkat 
kejenuhan amonium sulfat sampai pada $65 \%$, sedangkan pada tingkat kejenuhan selanjutnya kadar protein menurun.

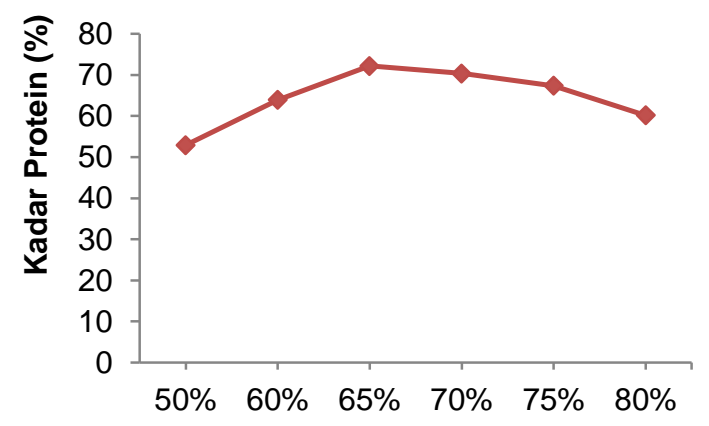

Tingkat Kejenuhan Amonium Sulfat

Gambar 2 Grafik hubungan tingkat kejenuhan amonium sulfat terhadap kadar protein

Kenaikan kadar protein protein seiring seiring dengan peningkatan rendemen. Pada proses salting out yang diinginkan adalah terjadi koagulasi protein yang ditambahkan suatu larutan garam sehingga terjadi peningkatan daya kelarutan (salting in) sampai titik maksimumnya, kemudian terjadi penurunan daya larutnya (salting out). Saat proses ini terjadi kompetisi diantara protein dan garam dalam menarik molekul air untuk proses pelarutan, maka interaksi antara protein dengan protein menjadi lebih penting (Bintang, 2010). Hal ini menyebabkan terjadinya proses koagulasi protein hingga menghasilkan konsentrat protein. Menurut Witono, et al. (2006), semakin banyak rendemen yang dihasilkan, maka kadar protein yang ada pada rendemen konsentrat protein tersebut semakin banyak. Hal ini diakibatkan jumlah protein yang terkoagulasi semakin banyak.
Hasil uji sidik ragam menunjukkan bahwa kadar protein dari tingkat kejenuhan amonium sulfat berpengaruh sangat nyata. Hasil analisis lanjut menggunakan BNJ menunjukkan rasio $65 \%$ memiliki nilai tertinggi dan berbeda nyata dengan perlakuan lainnya.

\section{Konsentrat Protein dari Berbagai Rasio Tepung Biji Kelor terhadap Amonium Sulfat Tingkat Kejenuhan 65\%}

Pembuatan konsentrat protein dipengaruhi oleh beberapa factor, diantaranya jumlah pengkoagulan untuk mengkoagulasi protein. Semakin banyak jumlah pengkoagulan maka kemampuannya untuk mengkoagulasi protein akan semakin besar (Kurniati, 2009).

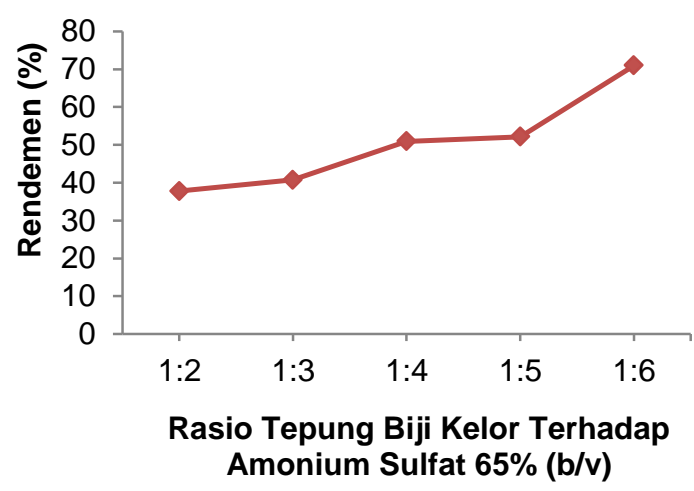

Gambar 3 Grafik hubungan rasio tepung biji kelor : amonium sulfat terhadap rendemen konsentrat protein

Gambar 3 menunjukkan semakin besar rasio tepung biji kelor terhadap amonium sulfat yang digunakan, maka rendemen konsentrat protein yang dihasilkan semakin tinggi. Jumlah pengkoagulan yang semakin besar banyak membuat interaksi antara tepung biji kelor dengan larutan amonium sulfat 
dalam proses salting out semakin meningkat, karena kompetisi diantara protein dan garam dalam menarik molekul air untuk proses pelarutan, sehingga interaksi protein dengan protein menjadi lebih penting.

Hasil uji sidik ragam menunjukkan rendemen konsentrat protein dari rasio tepung biji kelor terhadap amonium sulfat berbeda nyata. Hasil analisis lanjut menggunakan BNJ menunjukkan pada rasio 1:3, 1:4, dan 1:5 berbeda tidak nyata, sementara 1:2 dan 1:6 mempunyai perbedaan yang sangat nyata.

\section{Kadar Protein dari Berbagai Rasio Tepung Biji Kelor terhadap Amonium Sulfat}

Berdasarkan hasil yang diperoleh (Gambar 4) kadar protein meningkat seiring dengan meningkatnya rasio tepung biji kelor terhadap amonium sulfat yang diterapkan. Kadar protein terbaik diperoleh pada rasio 1:6.

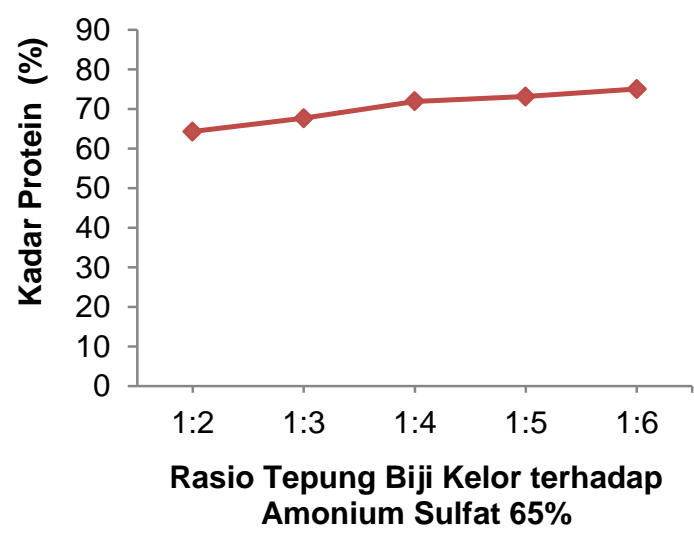

Gambar 4 Grafik hubungan konsentrat protein tepung biji kelor terhadap kadar protein

Hasil ini menunjukkan peningkatan kadar protein dari biji kelor yang awalnya $38,4 \%$, setelah dibuat menjadi konsentrat protein kadar kemurnian protein meningkat menjadi $75,05 \%$. Pada proses salting out, hanya protein yang terkoagulasi sehingga protein menjadi lebih murni bebas dari karbohidrat, lemak, air, dan mineral yang terkandung pada bahan sebelum proses pembuatan konsentrat protein.

Hasil uji sidik ragam menunjukkan kadar protein terhadap rasio konsentrat protein tepung biji kelor dan amonium sulfat berbeda sangat nyata. Hasil uji lanjut dengan BNJ menunjukkan pada rasio 1:4, 1:5 menunjukkan perbedaan nyata, sementara rasio $1: 2,1: 3$, dan 1:6 menunjukkan perbedaan yang sangat nyata. Dengan demikian rasio 1:6 adalah perlakuan terpilih untuk penentuan profil asam amino.

\section{Profil Asam Amino Konsentrat Protein Biji Kelor}

Hasil analisis profil asam amino dari konsentrat protein biji kelor menggunakan KCKT (Tabel 1) menunjukkan bahwa terdapat 18 jenis asam amino penyusun protein biji kelor, 10 jenis diantaranya diantaranya merupakan asam amino essensial dan 8 jenis merupakan asam amino non essensial. Asama amino essensial merupakan asam amino yang tidak dapat disintesis oleh tubuh, untuk mencukupi kebutuhannya maka diperlukan dari bahan makanan yang dapat mencukupinya. 
Tabel 1 Profil asam amino biji kelor

\begin{tabular}{clc}
\hline Jenis & \multicolumn{1}{c}{ Asam Amino } & $\begin{array}{c}\text { Kadar } \\
\text { (mg/g) }\end{array}$ \\
\hline \multirow{6}{*}{ Essensial } & Arginin (arg) & 77,33 \\
& Fenilalanin (phe) & 27,61 \\
& Leusin (leu) & 27,39 \\
& Valin (val) & 15,19 \\
& Isoleusin (ile) & 15,29 \\
& Histidin (his) & 13,16 \\
& Threonin (thr) & 11,29 \\
& Metionin (met) & 10,67 \\
& Lisin HCl (lys) & 7,57 \\
& Triptofan (try) & 3,49 \\
\hline \multirow{5}{*}{ Non } & Asam glutamat (glu) & 97,19 \\
& Prolin (pro) & 26,3 \\
essensial & Glisin (gly) & 24,74 \\
& Alanin (ala) & 17,57 \\
& Asam aspartat (asp) & 17,45 \\
& Serin (ser) & 15,16 \\
& Tirosin (tyr) & 11,29 \\
& Sistein (cys) & 5,9 \\
\hline
\end{tabular}

Tabel 1 menunjukkan asam amino essensial yang lengkap pada konsentrat protein biji kelor. Namun jika dibandingkan dengan pola asam amino baku FAO/WHO belum memenuhi jumlah asam amino yang dibutuhkan dalam setiap bahan pangan.

\section{KESIMPULAN}

Tingkat kejenuhan amonium sulfat terbaik diperoleh pada tingkat kejenuhan $65 \%$ dengan rendemen sebesar 46,56\% dan kadar protein sebesar $72,19 \%$. Rasio tepung biji kelor terhadap amonium sulfat tingkat kejenuhan terbaik diperoleh rasio terbaik diantara rasio yang diterapkan pada rasio 1:6 (b/v), dengan rendemen $70,96 \%$ dan kadar protein $74,16 \%$. Profil asam amino konsentrat protein biji kelor yaitu asam amino esensial $(\mathrm{mg} / \mathrm{g}$ ) berupa arginin $(77,3)$, fenilalanin $(27,61)$, leusin
$(27,39)$, valin $(15,19)$, isoleusin $(13,16)$, treonin $(11,29)$ metionin $(10,67)$, lisin $(7,57)$, lisin $(7,57)$, triptopan $(3,49)$. Asam amino non esensial $(\mathrm{mg} / \mathrm{g})$ berupa asam glutamat $(97,19)$, prolin $(26,3)$, glisin $(24,74)$, alanin $(17,57)$, asam aspartat $(17,45)$, serin $(15,16)$, tirosin $(11,29)$, dan sisitein $(5,9)$.

Rasio maksimum untuk memperoleh konsentrat protein belum diperoleh, kadar protein yang cukup tinggi serta asam amino esensial yang lengkap pada biji kelor dapat dipertimbangkan untuk dilakukan penelitian lanjutan dalam pemanfaatan konsentrat protein tersebut.

\section{DAFTAR PUSTAKA}

Bahri, S., Mirzan, M., Hasan, M. (2012). Karakteristik Enzim Amilase dari Kecambah Biji Jagung Ketan (Zae mays ceratine L.). Jurnal Natural Sciences, 1(1) : 132-143

Bintang, M. (2010). Biokimia Tehnik Penelitian Jakarta : Erlangga.

Elfita, L. (2014). Analisis Profil Protein dan Asam Amino Sarang Burung Walet (Collocalia Fuchiphaga) Asal Painan. Jurnal Sains Farmasi dan Klinis. 1(1) : 27-37

Hardi, J., \& Diharnaini, D. (2014). Penggunaan Protease dari Getah Biduri dalam Produksi Flavor Udang Windu (Penaeus monodon). Natural Science: Journal of Science and Technology, 3(2).

Hermiastuti, M. (2013). Analisis Kadar Protein dan Identifikasi Asam Amino Ikan Patin (Pangasius djambal). Skripsi. Jember: Jurusan Kimia FMIPA Jember.

Hutomo, G.S. (2004). Optimasi Ekstraksi Lipase dari Dedak Padi Varietas 
IR-64. Jurnal Agroland. 11 (1) : 32-36

Karnila, R., Astawan, M., Sukarno., Wresdiyati, T. (2011). Karakteristik Konsentrat Protein Teripang Pasir (Hulothuria scabra J.) dengan Pengestrak Aseton. Jurnal Perikanan dan Kelautan. 16 (1) : 90-102.

Kurniati, E. (2009). Pembuatan Konsentrat Protein dari Biji Kecipir dengan Penambahan $\mathrm{HCl}$. Jurnal Penelitian IImu Tehnik. 9 (2) : 115-122.

Laguni, N. (2012). Penggunaan Bungkil Biji Kelor (Moringa oleifera) sebagai Adsorben lon Fe (II) dan ion $\mathrm{Pb}$ (II). Skripsi. Palu: Jurusan Kimia FMIPA Universitas Tadulako.

Muchtadi, D. (2009). Pengantar IImu Gizi. Bandung : Alfabeta.

Nooralabettu K.P. (2014). Optimasi of Ammonium Sulfate Precipitation Method to Achieve High Throughtput Concentration of Crude Alkaline Phosphatase from Brown shrimp (Metapenaeus monoceros) Hepatopancreas. Int. J. Anal Bio-Sci. 2 (1) : 7-16

Purwitasari A., Hendrawan Y., Yulianingsih R. (2014). Pengaruh Suhu dan Waktu Ekstraksi terhadap Sifat Fisik Kimia dalam Pembuatan Konsentrat Protein Kacang Komak (Lablab purpureus L. Sweet). Jurnal Bioproses Komoditas Tropis. 2(1) : $42-53$

Rahmawati, A.T. (2009). Isolasi dan Karakterisasi Enzim Lipase
Getah Tanaman Biduri (Calletropis gigantean). Skripsi. Palu: Jurusan Kimia FMIPA Universitas Tadulako.

Sanusi, I., Sitorus, M. (2013). Tehnik Laboratorium Kimia Organik. Yogyakarta : Graha IImu.

Srawaili N. (2008). Efektivitas Biji Kelor (Moringa oleifera) dalam Menurunkan Kekeruhan, Kadar Ion Besi dan Mangan dalam Air. Tesis. Bandung: Program Studi Kimia Institut Tehnologi Bandung.

Su'i M.S. (2013). Fraksinasi Enzim Lipase dari Endosperm Kelapa dengan Metode Salting Out. Jurnal Agritech. 33 (4) : 377-383

Sumantri A.R. (2007). Analisis Makanan. Yogyakarta : Gajah Mada University Press.

Tejasari. (2005). Nilai Gizi Pangan. Yogyakarta : Graha IImu.

Timumun M.I. (2012). Isolasi Lipase Daun Pepaya (Carica papaya L.) Varietas Lokal dan Aplikasinya dalam Biosintesis Monolaurin. Skripsi. Palu: Jurusan Kimia FMIPA Universitas Tadulako.

Witono Y., Aulanni'am., Subagio A., Bambang, Simon. (2006). Pemurnian Parsial Enzim Protease dari Getah Tanaman Biduri (Calletropis gigantean) menggunakan Amonium Sulfate. Jurnal Teknologi Pertanian. 7 (1) : 20-26

Yuniastuti A. (2008). Gizi dan Kesehatan. Yogyakarta : Graha IImu 